\title{
Rhythm of Seasonal Development and Minor Life Cycle of Prunella vulgaris L. (Lamiaceae) in Khakasia
}

\author{
Vera A. Cheryomushkina ${ }^{a}$ and Irina N. Barsukova*b \\ ${ }^{a}$ Central Siberian Botanical Garden SB RAS \\ Novosibirsk, Russian Federation \\ ${ }^{b}$ Katanov Khakass State University \\ Abakan, Russian Federation
}

Received 16.02.2017, received in revised form 02.05.2017, accepted 14.06.2017, published online 20.05.2019

\begin{abstract}
Seasonal rhythms of plant development are related to plant adaptation to surrounding ecological coenotic and climatic conditions. To discover the patterns of seasonal development of plants in different phytocoenoses, it is essential to observe individual shoots and the entire course of shoot formation. So far the data on the rhythm of seasonal development of Prunella vulgaris L., a plant of the circumboreal region, have been available for the European part of Russia only. We examined the rhythm of seasonal development and minor life cycle of Prunella vulgaris L., the long-rhizome life form, in Siberia (Khakasia) in 2012-2013. Observations were carried out in a forest meadow every 5-7 days in the spring-summer-autumn period and 1-2 times a month in the winter. The development of dicyclic meso-rosetted and winter monocyclic semi-rosetted generative monocarpic shoots was observed using the method by I.G. Serebryakov. It was determined that the differentiation of vegetative and generative spheres in Prunella vulgaris L. shoots in Siberia occurs in early spring within the year of flowering. The species forms spring and autumn leaf generations and phenologically can be described as a summer-winter green plant with a long growing season. The period of shoot development from its initiation to dying the above-ground parts lasts 26 and 14 months in dicyclic meso-rosetted shoots and winter monocyclic semi-rosetted shoots, respectively. In both cases the development of the primordial shoot inside the bud lasts 8 months while the duration of shoot development after emerging from the bud varies. The latter phase lasts 18 months in dicyclic meso-rosetted shoots and only 6 months in winter monocyclic semi-rosetted shoots. Start times and duration of phenological phases (budding, flowering, fruiting and dissemination) are related to the weather conditions in the habitats including fluctuations in air temperature, precipitation patterns and types.
\end{abstract}

(C) Siberian Federal University. All rights reserved

This work is licensed under a Creative Commons Attribution-NonCommercial 4.0 International License (CC BY-NC 4.0).

* Corresponding author E-mail address: saphronovairina@mail.ru 
Keywords: Prunella vulgaris L., minor life cycle, shoot formation, seasonal development, phenological phase, Khakasia.

Citation: Cheryomushkina V.A., Barsukova I.N. Rhythm of seasonal development and minor life cycle of Prunella vulgaris L. (Lamiaceae) in Khakasia. J. Sib. Fed. Univ. Biol., 2020, 13(1), 94-108. DOI: 10.17516/1997-1389-0295

\title{
Ритм сезонного развития и малый жизненный цикл Prunella vulgaris L. (Lamiaceae) в Хакасии
}

\author{
В.А. Черемушкина ${ }^{\text {a }}$ И.Н. Барсукова ${ }^{6}$

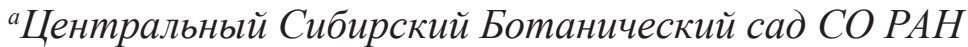 \\ Российская Федерация, Новосибирск \\ ${ }^{6}$ Хакасский государственный университет им. Н.Ф. Катанова \\ Российская Федерачия, Абакан
}

\begin{abstract}
Аннотация. Ритмы сезонного развития растений отражают их приспособление к окружающим эколого-ценотическим и климатическим условиям произрастания. Раскрытие закономерностей сезонного развития растений в разных фитоценозах возможно только при изучении каждого отдельного побега и хода побегообразования в целом. Материалы о сезонном ритме развития Prunella vulgaris L., имеющего циркумбореальный ареал, касаются только европейской части России. В связи с этим нами в 2012-2013 гг. в Сибири (Хакасия) изучен ритм сезонного развития и малый жизненный цикл растений Prunella vulgaris L. длиннокорневищной жизненной формы. Наблюдения за генеративными монокарпическими побегами - дициклическими среднерозеточными и озимыми моноциклическими полурозеточными - проводили в условиях лесного луга, в весеннелетне-осенний период через 5-7 дней, в зимний - 1-2 раза в месяц. В работе использована методика И.Г. Серебрякова. Установлено, что дифференциация вегетативной и генеративной сфер у побегов Prunella vulgaris L. в Сибири происходит ранней весной в год цветения особи. Растения формируют весеннюю и осеннюю генерации листьев и по характеру фенологического развития относятся к длительно вегетирующим летне-зимне-зеленым. От момента заложения до отмирания надземной части период развития дициклического среднерозеточного и озимого моноциклического полурозеточного монокарпических побегов длится 26 и 14 месяцев соответственно. При этом на внутрипочечную фазу развития приходится 8 месяцев. Продолжительность внепочечной фазы развития различается и составляет у дициклического среднерозеточного побега 18 месяцев, у озимого моноциклического полурозеточного побега всего 6 месяцев. Сроки наступления фенологических фаз (бутонизация, цветение, плодоношение, рассеивание эремов) и их продолжительность связаны с погодными условиями местообитания особей: колебаниями температуры воздуха, количеством осадков и характером их распределения, высотой снежного покрова и временем его схода.
\end{abstract}


Ключевые слова: Prunella vulgaris L., малый жизненный цикл, побегообразование, сезонное развитие, фенологическая фаза, Хакасия.

Цитирование: Черемушкина, B.А. Ритм сезонного развития и малый жизненный цикл Prunella vulgaris L. (Lamiaceae) в Хакасии / В.А. Черемушкина, И.Н. Барсукова // Журн. Сиб. федер. ун-та. Биология, 2020. 13(1). С. 94-108. DOI: $10.17516 / 1997-1389-0295$

\section{Введение}

Наиболее характерной чертой любой биологической системы выступает ритмичность ее жизненных процессов во времени (Сабинин, 1957; Shorina, Derzhavina, 2015). Ритмика растительных организмов проявляется в периодичности их сезонного развития. Вслед за И.Г. Серебряковым (1947) под ритмом сезонного развития мы понимаем ежегодно повторяющееся закономерное чередование определенных биологических процессов и фаз, обычно совпадающее с климатической и формационной ритмикой. Ритмы сезонного развития неодинаковы у разных видов растений. Разнообразие их ритмического поведения в основе своей определяется внутренними закономерностями развития растительных организмов, а также различными мощными и постоянными внешними факторами-регуляторами, которые обуславливают развитие растения в данном местообитании (Серебряков, 1966; Борисова, 1972; Серебрякова, 1976).

Проблеме ритма развития растений и растительных сообществ в целом посвящены работы многих ботаников. В них установлено, что одним из условий глубокого познания и раскрытия закономерностей сезонного развития растений разных фитоценозов является изучение каждого отдельного побега и всего хода побегообразования (Серебряков, 1947, 1966; Борисова, 1972; Серебрякова, 1976; Черемушкина, 2004; Безделева, 2010; Никифоров, 2011;
Gorchakova, 2013; Shorina, Derzhavina, 2015 и др.).

Prunella vulgaris L. (Lamiaceae Lindl.) черноголовка обыкновенная - имеет обширный ареал, включающий Евразию, Австралию, северную часть Африки и Северную Америку. На евразийском континенте вид простирается от Британских островов до Дальнего Востока, на севере доходит до Арктической зоны, южной границей являются территории Центральной, Юго-Западной и Юго-Восточной Азии (Борисова, 1954; Smith, 1972; Xi-wen, Hedge, 1994). На всем протяжении своего циркумбореального ареала P. vulgaris обычно произрастает в полосе предгорий и низкогорий; на лесных опушках, в разреженных березовых лесах и осиновых перелесках, в зарослях кустарников, на влажных, иногда засоленных лугах и полянах, по берегам озер, стариц, на прирусловых галечниках, вдоль лесных дорог. В Сибири для P. vulgaris характерна приуроченность к лесостепному и лесному поясам растительности. Ее распространение связано с открытыми, умеренно увлажненными растительными сообществами в составе настоящих, реже - лесных лугов и лишь единично остепненных лугов и зональных гемибореальных лесов (Ermakov, Maltseva, 1999; Королюк, Макунина, 2001). Также местообитания вида могут быть приурочены к несформированным сообществам (на отвалах щебня, по обочинам дорог) с сильным антропогенным воздействием. Встречается 
на песчаных и на более тяжелых (суглинистых) почвах.

Материалы о сезонном ритме развития P. vulgaris разнообразны, но, как правило, касаются европейской части России (Серебряков, 1947; Серебрякова, 1956; БорисоваГуленкова, 1960; Денисова, 1960; Андреева, 1964). Сведения о сезонном и малом жизненном цикле $P$. vulgaris в Сибири отсутствуют.

Цель исследования - изучение сезонного ритма развития и малого жизненного цикла P. vulgaris в Хакасии.

\section{Материалы и методы}

Исследования, ранее проведенные на территории Сибири, показали, что P. vulgaris это симподиально нарастающее многолетнее травянистое поликарпическое растение, формирующее на территории Хакасии длиннокорневищную и кистекорневую жизненные формы (Барсукова, Черемушкина, 2014). Сезонное развитие и малый жизненный цикл изучены у особей с наиболее часто встречаемой длиннокорневищной биоморфой.

Исследование проводили в 2012-2013 гг. в Бейском районе Республики Хакасия в окрестностях города Саяногорска $\left(53^{\circ} 00^{\prime} 88,7^{\prime \prime}\right.$ с.ш., 91²27'67,6" в.д., 343 м над ур. м.) на мятликово-ежовом (Dactylis glomerata L., Poa sibirica Roshev., Alchemilla xanthochlora Rothm., Carum carvi L.) лесном лугу (общее проективное покрытие - 98 \%, проективное покрытие вида - 5 \%). Осуществляли наблюдения за приводящими к разрастанию особи P. vulgaris монокарпическими побегами: дициклическими среднерозеточными и озимыми моноциклическими полурозеточными.

В работе использовали методику И.Г. Серебрякова (1947). При изучении побегообразования генеративные особи выкапывали в весенне-летне-осенний период с периодичностью в 5-7 дней, в зимний - 1-2 раза в ме- сяц. Под малым жизненным циклом, вслед за С.П. Смеловым (1966), мы понимаем развитие побега от заложения почки до отмирания его надземной части. Малый жизненный цикл описывали на основе анализа 5-10 особей в каждый срок наблюдения. Предварительно особи фиксировали в смеси спирт-глицеринвода в соотношении 1:1:1. Почки возобновления просматривали при помощи стереомикроскопа Stemi DV4 (Zeiss). Полученные данные по ритмике годичного развития оформляли в виде графиков по типу, предложенному И.Г. Серебряковым (1947), где детально отображается ритмика развития листового аппарата и почек возобновления. Принадлежность к феноритмотипу определяли согласно классификации И.В. Борисовой (1972).

\section{Результаты и обсуждение}

В зрелом генеративном онтогенетическом состоянии побеговая система особи представляет собой симподий, состоящий из последовательно сменяющих друг друга побегов разных порядков. Как правило, он образуется за счет развертывания почек в зоне возобновления побега (апогеотропная часть), которая состоит из 2-5 метамеров. Однако иногда в рост могут пойти перезимовавшие или спящие почки на плагиотропных участках корневищ и образовывать побеги разрастания (Барсукова, Черемушкина, 2014). В этой работе рассмотрен наиболее типичный случай малого жизненного цикла дициклического среднерозеточного и озимого моноциклического полурозеточного монокарпических побегов P. vulgaris.

\section{Развитие дициклического}

среднерозеточного побега

К началу фазы созревания семян побега I порядка (середина-конец июля) на побеге II порядка появляется розеточная часть. Одно- 
временно с ней происходит заложение дициклических побегов III порядка (рис. 1). Таким образом, во второй декаде июля - первой декаде августа в верхней или нижней, а иногда и в средней частях зоны возобновления побега II порядка хорошо различимы 1-4 дициклических побега. К концу августа в открытой почке таких побегов заметны 3 зеленых листовых зачатка с почками в первом из них. Наступление холодного времени года (осень, зима) приводит к перерыву в деятельности конуса нарастания и возникновению незрелой «почки в почке» (термин Т.И. Серебряковой (1971)). С появлением первых теплых дней и началом таяния снега (середина марта) начинается новый период активности конусов нарастания побегов II и III порядков. В результате быстрого дозакладывания 2-3 листовых зачатков к этому времени в розеточной части побега возобновления II порядка развернуты 5-8-ой зеленые листья и сформирована генеративная сфера соцветия. Терминальная почка побега III порядка идет в рост, отчленяет одну пару ассимилирующих листьев, в пазухах которых заложены почки.

К третьей декаде мая-первой декаде июня ортотропная часть побега II порядка вытягивается, на ней разворачиваются 2-3 пары листьев с почками, появляются бутоны. К этому времени у дициклического побега III порядка хорошо заметен участок из удлиненных метамеров с молодыми придаточными корнями. Он состоит из 3-7 узлов и 2-6 пар ассимилирующих листьев (первая пара листьев отмирает в мае). Емкость его верхушечной почки - 2 листовых зачатка, почки в их пазухах отсутствуют.

К середине - концу июля на побеге III порядка появляется розеточная часть и закладывается дициклический побег следующего порядка. На розеточной части начинают развертываться листья осенней генерации, и к третьей декаде августа их число достигает 4-7 пар. Таким образом, дициклический побег (его апогеотропная и ортотропная части) P. vulgaris несет до 7-11 пар листьев двух генераций.

В третьей декаде августа - первой декаде сентября побег возобновления III порядка полегает, укореняется и входит в состав симподиального эпигеогенного корневища. На его плагиотропной части сохраняются остатки отмерших листьев весенней генерации, в пазухах которых заложены почки. Иногда некоторые из них в летне-осенний период трогаются в рост с образованием 1-3 дициклических среднерозеточных монокарпических или моноциклических удлиненных побегов, остальные почки становятся спящими и отмирают либо просыпаются позже. Ортотропная часть побега II порядка отмирает (рис. 1).

В розеточной части побега возобновления III порядка, в пазухах всех листьев осенней генерации ко второй декаде августа заложены почки длиной до 1 мм. В каждой из них хорошо различимы по 3 зачаточных ассимилирующих листа. К началу осени все почки вегетативные, у них лишь частично сформирована вегетативная сфера будущего побега.

Период развития дициклического среднерозеточного монокарпического побега от момента заложения до отмирания его надземной ортотропной части длится около 26 месяцев (2,2 года), из них на внутрипочечную фазу развития приходится 8 месяцев, внепочечную - 18 месяцев (1,5 года).

\section{Развитие озимого моноциклического полурозеточного побега}

В верхней или средней, а иногда и в нижней частях зоны возобновления побега II порядка одновременно с заложением дициклических побегов закладываются 1-4 озимых моноциклических побега (рис. 1). Ко второй 


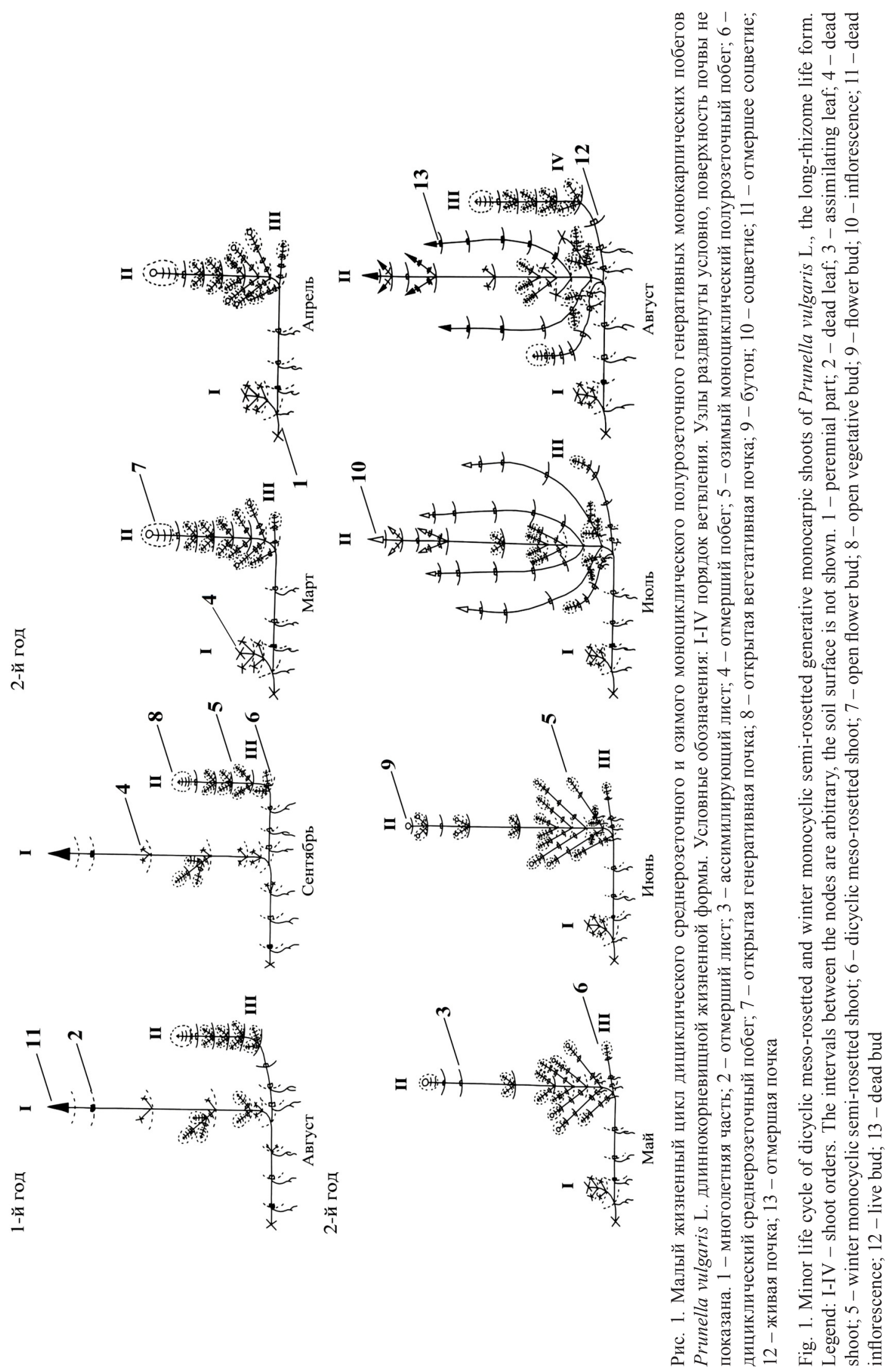


декаде сентября почки таких побегов увеличиваются и идут в рост. Происходит удлинение первого междоузлия, раскрывается первая пара зеленых ассимилирующих листьев. Емкость верхушечной почки - 3 зачатка, в пазухах первого листового зачатка различимы почки. Генеративная сфера озимого моноциклического побега к концу осени не сформирована, ее заложение, так же как и у дициклического среднерозеточного побега, происходит лишь в год цветения (середина марта) после дозакладывания вегетативных зачатков. Это явление подтверждает сведения И.Г. Серебрякова (1947), также изучавшего у P. vulgaris степень сформированности побега будущего года в почках возобновления. Его исследования позволили отнести изучаемый вид к третьей группе растений, у которых к концу вегетационного периода даже вегетативная часть побегов в почках возобновления сформирована не полностью.

Ранней весной следующего года, одновременно с развертыванием листьев на побеге II порядка, начинается рост озимых моноциклических побегов. К концу весны на их базальной части хорошо заметны молодые придаточные корни и 2-3 сближенных узла с почками.

В третьей декаде июня - начале июля моноциклические побеги вытягиваются с формированием удлиненной ортотропной части, укореняются и зацветают. Одновременно с образованием удлиненной области, почки, находящиеся в базальной части побега, незначительно увеличиваются в размерах. В них становятся хорошо заметными 3 листовых зачатка, иногда в первом из них уже заложены пазушные почки. К концу лета надземная часть озимых моноциклических побегов отмирает до базальной части. В результате развертывания вышеописанных жизнеспособных почек образуются новые моно- и дициклические побеги возобновления.

Период развития озимого моноциклического полурозеточного побега от момента заложения до отмирания его удлиненной части длится около 14 месяцев (1,2 года).

Впервые на образование двух генераций побегов у P. vulgaris в течение года указал И.Г. Серебряков (1947), изучая ритмику развития листового аппарата у растений подмосковных лесов. Позднее, рассматривая закономерности побегообразования P. vulgaris на заливных лугах Дединовской поймы р. Оки (Московская область), Т.И. Серебрякова (1956) предполагала возможное сочетание дициклических и озимых побегов у этого вида. Причем, по ее мнению, озимые побеги характеризовались развитием листьев весенне-летней и осенне-зимней генераций. Исследования Г.М. Денисовой (1960) на лугах низовий Северной Двины и М.А. Борисовой-Гуленковой (1960) в Стрелецкой степи Курской области также показывают образование у P. vulgaris двух генераций побегов. Приводя результаты сравнительного анализа ритма развития и побегообразования P. vulgaris в Московской области и на Батумском побережье Кавказа, И.И. Андреева (1964) указывает, что в г. Батуми черноголовка обыкновенная может развивать за год до четырех генераций побегов. Эти побеги могут трогаться в рост в разное время - перед зацветанием материнского побега или перед его отмиранием. Таким образом, приспособление к более длительному вегетационному периоду у вида идет в сторону увеличения числа генераций побегов в течение года.

\section{Сезонный ритм развития $P$. vulgaris}

Согласно классификации И.В. Борисовой (1972) P. vulgaris по характеру фенологического развития в годичном цикле относится к дли- 
тельно вегетирующим летне-зимне-зеленым растениям. В течение вегетационного сезона особи P. vulgaris проходят четыре фенологические фазы: вегетация, бутонизация, цветение, плодоношение и рассеивание эремов (рис. 2).

Так как P. vulgaris характеризуется наличием двух генераций листьев (весенней и осенней), фаза вегетации происходит в течение всего года. В связи с тем что заложение листьев у дициклических среднерозеточных и озимых моноциклических полурозеточных монокарпических побегов различается во времени, рассмотрим их по отдельности.
В середине - конце марта с началом теплых дней, но еще до таяния снега начинают развертываться верхушечные почки перезимовавших дициклических побегов II и III порядков, образуя листья весенней генерации. Одновременно с этим на дициклических побегах II порядка начинают постепенно отмирать перезимовавшие листья осенней генерации. К середине июня наблюдается отмирание всех листьев осенней генерации. Вегетация осуществляется за счет листьев весенней генерации побегов II и III порядков.

На дициклическом среднерозеточном монокарпическом побеге III порядка к середине июля происходит развертывание листьев

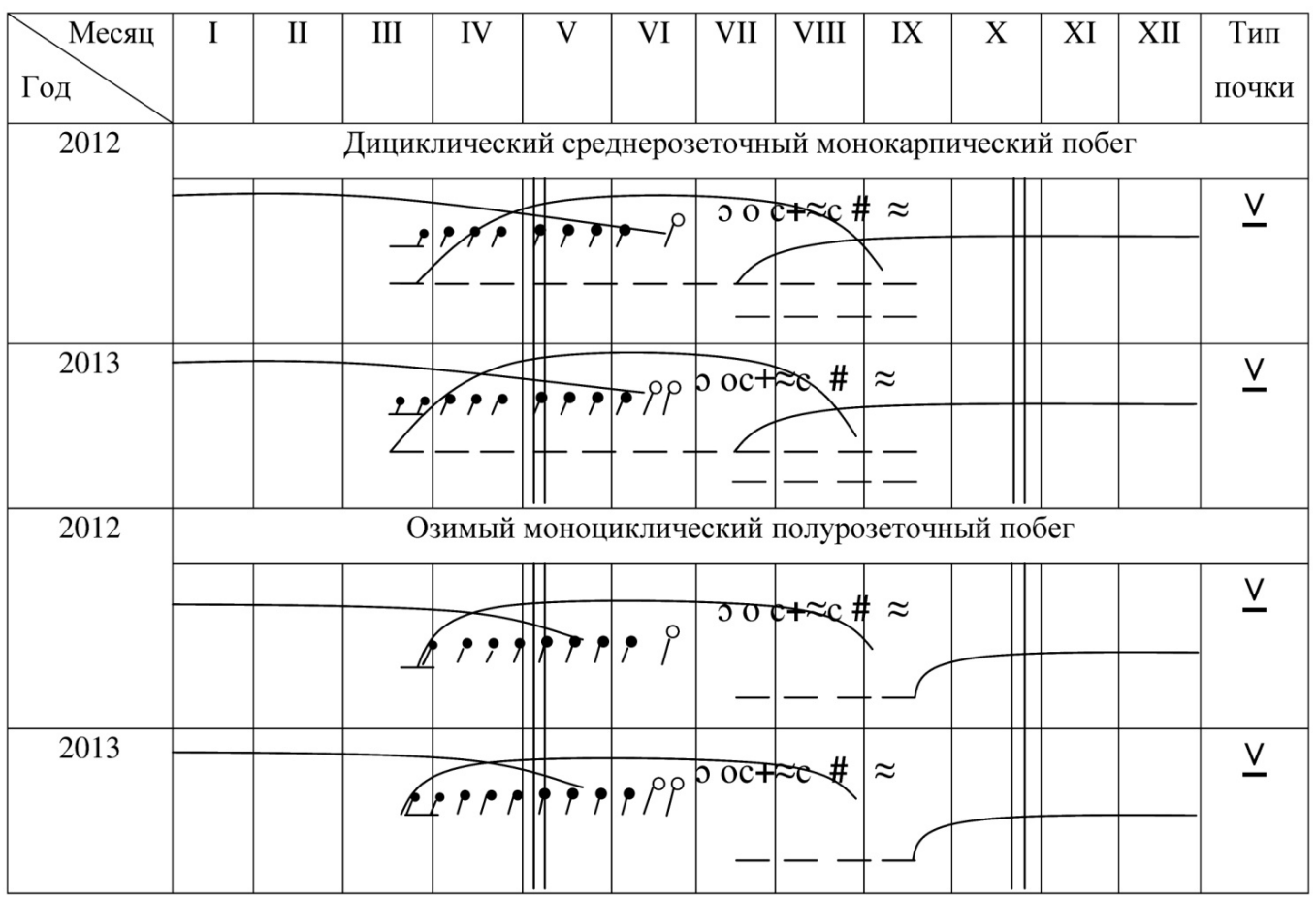

Рис. 2. Сезонное развитие растений Prunella vulgaris L. длиннокорневищной жизненной формы. Условные обозначения: || - установление и сход снежного покрова; - - - заложение листьев в почках; изменение общей листовой поверхности; $\underline{v}$ - открытая почка; $\boldsymbol{\bullet} \bullet \boldsymbol{\varphi}$ - заложение соцветия в почках; 9 ९ - бутонизация; - - начало цветения; о - массовое цветение; с - окончание цветения; +\# - плодоношение; $\approx$ - рассеивание эремов

Fig. 2. Seasonal development of Prunella vulgaris L. plants, the long-rhizome life form. Legend: \| - establishment and loss of snow cover; - - - initiation of leaves in the buds; - change in the total leaf surface; $\underline{v}$ - open bud; $\boldsymbol{\varphi} \boldsymbol{\varphi}$ - initiation of inflorescences in the buds; $९ \varphi$ - flower bud formation; $\curvearrowright$ - start of flowering; $o$ - mass flowering; $\mathrm{c}$ - end of flowering; + \# - fruiting; $\approx-$ dissemination 
осенней генерации и начинается постепенное отмирание листьев весенней генерации. К этому времени ортотропная часть побега возобновления II порядка также теряет листья и начинает отмирать. К концу сентября вегетация уменьшается. На дициклическом среднерозеточном монокарпическом побеге III порядка P. vulgaris сформированы 4-7 пар зеленых листьев. В таком состоянии растение переживает зиму и до весны следующего года остается зеленым.

Несколько отличается развертывание листьев на озимых моноциклических полурозеточных побегах. Так, первая пара зеленых листьев осенней генерации появляется уже в год заложения побега, ко второй декаде сентября. На следующий год, с появлением первой весенней оттепели, происходит разворачивание листьев весенней генерации. Ко второй декаде мая листья осенней генерации постепенно желтеют и отмирают. Весенняя генерация листьев сохраняется в течение всего вегетационного сезона и погибает вместе с удлиненной частью озимого моноциклического побега.

От момента заложения дициклических среднерозеточных побегов до появления у них генеративных зачатков проходит около 21 месяца, у озимых моноциклических полурозеточных побегов около 9 месяцев. Интенсивный рост побегов начинается с момента развертывания первых листьев весенней генерации, фаза бутонизации наступает через 2,5 месяца и длится около 2-3 недель. Цветение P. vulgaris длится около 3-3,5 недель: в конце июня - первых числах июля зацветают единичные особи, массовое цветение приходится на середину июля, а в третьей декаде июля оно заканчивается. Однако единичные особи продолжают цвести еще до середины августа. На одном дициклическом среднерозеточном побеге формируются 1-3 озимых моноциклических полурозеточных и моноциклических удлиненных генеративных побега. В дальнейшем моноциклические удлиненные генеративные побеги могут отмирать до базальной части, на которой остаются жизнеспособные почки, или полностью. Цветение происходит акропетально и характеризуется постепенным распусканием сначала нижних и средних цветков в соцветии, а затем верхних. Период цветения одного генеративного побега колеблется от 6 до 11 дней.

Одновременно с окончанием цветения начинают завязываться и созревать плоды нижних и средних цветков в соцветиях, особи P. vulgaris вступают в фазу плодоношения, которая в среднем происходит в течение 10-16 дней. Рассеивание эремов наступает в первой декаде августа и длится около трех-четырех недель. Как правило, оно осуществляется на небольшом расстоянии от материнской особи в результате раскачивания генеративных побегов ветром, животными, человеком или происходит во время дождя.

Ежегодно изменяющиеся климатические условия оказывают влияние на фенологическую пластичность растений, проявляющуюся в фенологических реакциях (продолжительность, выпадение или повторение фенологических фаз развития) (Жмылев и др., 2001; Никифоров, 2010; Олишевская, 2011; Gorchakova, 2013 и др.). В настоящее время среди ботаников широко распространено мнение о том, что колебания температуры воздуха, количество осадков, характер их распределения в течение года, а также высота и время схода снежного покрова накладывают свой отпечаток на ритм сезонного развития растений (Ahas et al., 2000; Wielgolaski, 2001; Beaubien, Hamann, 2011; Жмылева и др., 2011 и др.).

Среднемесячные температуры 2012-2013

гг. исследования отличаются незначитель- 
но (рис. 3). Климатические условия 2012 г. в целом характеризуются более жарким летом (июнь, июль) и теплой осенью (сентябрь). Однако начало весны (март, апрель) оказалось теплее в 2013 году. Температура воздуха в отдельные месяцы 2013 г. по сравнению с 2012 г. холоднее всего на $2-3{ }^{\circ} \mathrm{C}$.

Большим количеством осадков, по сравнению с 2013 г., характеризуется весенний (апрель, май), летний (июнь) и осенний (октябрь, ноябрь) периоды 2012 г. Осадки практически отсутствуют в зимний период 2012-2013 гг. На территории исследования устойчивый снежный покров появляется к третьей декаде октября и сходит к первой декаде мая. Зимний и весенний периоды 2012 г. характеризуются наибольшей высотой снежного покрова. В 2013 г. снег полностью сошел к апрелю, однако в первых числах мая был зарегистрирован небольшой снегопад. Осень 2013 г. характеризовалась более высоким уровнем снежного покрова.

В связи с изменениями погодных условий в 2012 г. фаза бутонизации началась 22 июня, а в 2013 г. - 16 июня. Продолжительность фенофазы составила 16 дней. Цветение особей происходило с 8 (2012 г.) и 2 (2013 г.) июля по 1 августа (2012 г.) и 22 июля (2013 г.). Длительность фазы цветения составила 25 (2012 г.) и 21 (2013 г.) день. В 2012 г. отдельные особи продолжали цвести до 16 , а в 2013 г. - до 10 августа. Начало плодоношения зафиксировано 26 (2012 г.) и 17 (2013 г.) июля, а разгар - 4 августа (2012 г.) (у отдельных особей 30 августа) и 27 июля (2013 г.) (у отдельных особей 20 августа). В 2012 г. массовое рассеивание эремов началось с 15 августа (у отдельных особей с 12 сентября), а в 2013 г. уже с 5 августа (у отдельных особей с 4 сентября). Продолжительность фазы рассеивания эремов составила в среднем 12 (2012 г.) и 10 дней (2013 г.).
Еще в середине прошлого века И.Г. Серебряков (1966), анализируя закономерности ритма сезонного развития растений разных природных зон, приходит к выводу о том, что важнейшие признаки годичного ритма роста и развития (строение и развитие почек, время заложения генеративных органов, время заложения монокарпического побега и особенности развития листового аппарата) диктуются внутренними закономерностями (эндогенными ритмами).

Анализ годичного ритма развития P. vulgaris и его сопоставление с ритмом развития особей вида в других регионах показал, что на территории Республики Хакасия, так же как и в европейской части России (Серебряков, 1947; Серебрякова, 1956; Борисова-Гуленкова, 1960; Денисова, 1960), дозакладывание вегетативных и формирование генеративных зачатков у $P$. vulgaris происходит весной в год цветения, у особей образуются весенняя и осенняя генерации листьев. В Московской области, согласно мнению Т.И. Серебряковой (1956), развитие листьев весенне-летней и осенне-зимней генераций происходит на озимых монокарпических побегах черноголовки. В отличие от этого в Сибири как монокарпические дициклические среднерозеточные, так и озимые моноциклические полурозеточные генеративные побеги характеризуются наличием двух листовых генераций. Однако, несмотря на незначительные отличия, годичный ритм P. vulgaris имеет эндогенный характер и связан с ритмической деятельностью конуса нарастания, на котором периодически образуются фитомеры, что приводит к чередованию циклов внутрипочечного и видимого роста. Подобные закономерности были установлены ранее и у других видов растений. Так, сопоставление ритма и темпов формирования почек и побегов у ряда травянистых расте- 


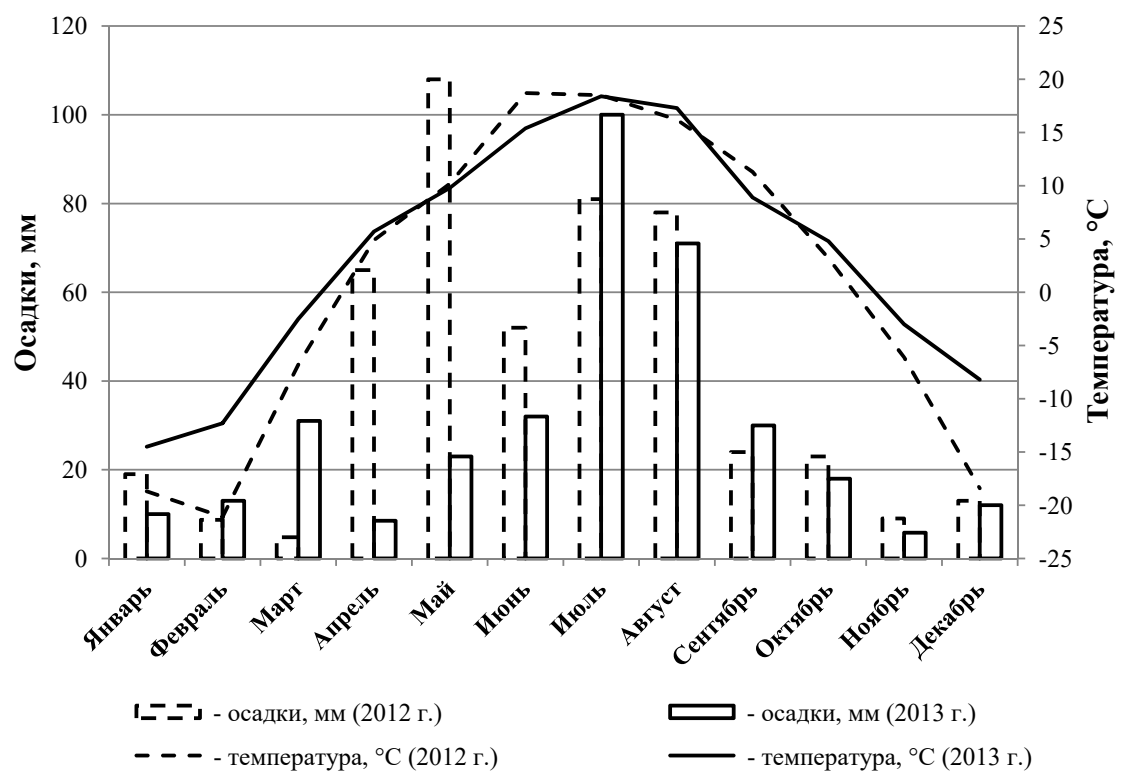

Рис. 3. Климатограмма 2012-2013 гг. (данные получены с сайта http://rp5.ru)

Fig. 3. Climatogram, 2012-2013 (based on the data from http://rp5.ru)

ний (Серебрякова, 1971; Шилова, 1988; Черемушкина, 2004) показало, что у одних видов внутрипочечное и внепочечное развитие побегов идет параллельно, у других процессы формообразования и развертывания фитомеров чередуются во времени, а у растений одного и того же вида в разных частях ареала и в годы, различающиеся по погодным условиям, ритмы и темпы внутрипочечного роста довольно сходны. Таким образом, к настоящему времени сформировалось представление о том, что каждый вид имеет специфичный внутрипочечный и внепочечный ритм развития побегов, который отражается в их структуре и который можно объяснить особенностями эволюции таксона.

В то же время ритм внепочечной фазы развития побега соответствует климатическим ритмам того или иного региона и отражает адаптацию вида к условиям произрастания, что хорошо проявляется в фенологическом развитии $P$. vulgaris в разных частях ареала. На территории Грузии и ев- ропейской части России P. vulgaris проходит фенологические фазы бутонизации, цветения, плодоношения и рассеивания эремов (Андреева, 1964). Однако на Батумском побережье Кавказа вид вегетирует в течение круглого года, поэтому в любое время года черноголовку можно встретить в состоянии вегетации и цветения. Наступление фенофаз в Московской области, как правило, происходит в среднем на 1-1,5 недели раньше, чем на территории нашего исследования. Так, фаза бутонизации наступает в первой декаде июня. В конце июня особи переходят к цветению. Продолжительность массового цветения, по сравнению с нашими данными, увеличивается, оно начинается с первой декады июля и может продолжаться до середины сентября. Фазы окончания цветения и плодоношения на территории европейской части также более продолжительны. Плодоношение начинается с середины июля и длится до конца сентября, тогда как в Хакасии оно заканчивается в конце августа. Рас- 
сеивание эремов зарегистрировано в начале октября, что почти на 3-3,5 недели позже, чем на территории Сибири.

\section{Заключение}

На территории Республики Хакасия окончательная дифференциация вегетативной и генеративной сфер у побегов разрастания $P$. vulgaris происходит только ранней весной в год цветения особи. Особи вида формируют весеннюю и осеннюю генерации листьев, вследствие чего вегетируют в течение круглого года и относятся по феноритмотипу к длительно вегетирующим летне-зимнезеленым растениям.

Период развития дициклического среднерозеточного монокарпического побега от момента заложения до отмирания его надземной ортотропной части длится около 26 месяцев, из них на внутрипочечную фазу развития приходится 8 месяцев, внепочечную - 18 месяцев. Внутрипочечная фаза развития озимо- го моноциклического полурозеточного побега составляет 8 , а внепочечная - 6 месяцев.

Анализ сезонного развития $P$. vulgaris позволяет говорить о том, что прохождение видом фаз бутонизации, цветения, плодоношения и рассеивания эремов соответствует климатическим условиям местообитания особей. В Московской области P. vulgaris проходит в своем развитии такие же фенологические фазы, однако наступают они на 1-1,5 недели раньше. Фазы массового цветения, окончания цветения и плодоношения более растянуты. Обсеменение заканчивается в октябре.

Сроки наступления фенологических фаз в 2012-2013 гг. наблюдений отличались на 6-10 дней. Изменчивость в продолжительности фаз связана с погодными условиями местообитания особей: колебаниями температуры воздуха, количеством осадков и характером их распределения, высотой снежного покрова и временем его схода.

\section{Благодарности / Acknowledgements}

Работа выполнена при финансовой поддержке в рамках проекта Государственного задания № 0312-2016-0003 и гранта РФФИ в рамках научного проекта № 14-44-04021 р_сибирь_а.

This work was financially supported in the framework of State Assignment No. 3212-206-0003 and the RFBR grant within the framework of Scientific Project No. 14-44-04021 r-siberia-a.

\section{Список литературы / References}

Андреева И.И. (1964) Побегообразование и ритм сезонного развития одноименных видов в Московской области и на Батумском побережье. Бюллетень Главного ботанического сада, 54 : 9-16 [Andreeva I.I. (1964) Shoot formation and seasonal rhythms of development of the eponymous species in the Moscow region and on the Batum coast. Bulletin of Main botanical garden [Byulleten' Glavnogo botanicheskogo sada], 54: 9-16 (in Russian)]

Барсукова И.Н., Черемушкина В.А. (2014) Онтогенез и жизненная форма Prunella vulgaris (Lamiaceae) в Республике Хакасия. Растительные ресурсы, 50(3): 347-359 [Barsukova I.N., Cheryomushkina V.A. (2014) Ontogenesis and life forms of Prunella vulgaris (Lamiaceae) in Khakasiya Republic. Plant Resources [Rastitelnye resursy], 50(3): 347-359 (in Russian)]

Безделева Т.А. (2010) Биология и ритм сезонного развития Вечерницы Ночной фиалки (Hesperis matronalis L.). Бюллетень Ботанического сада-института ДВО РАН, 7: 126-134 [Bezdeleva T.A. (2010) Biology and rhythm of seasonal development of Hesperis matronalis L. Bulletin 
of Botanical Garden-Institute FEB RAS [Byulleten' Botanicheskogo sada-instituta DVO RAN], 7: 126-134 (in Russian)]

Борисова А.Г. (1954) Черноголовка - Prunella L. Флора СССР. Том 20. Шишкин Б.К., Юзепчук С.В. (ред.) М., Л., Академия Наук СССР, с. 494-498 [Borisova A.G. (1954) Self-heal - Prunella L. Flora of the USSR. Vol. 20. Shishkin B.K., Yuzepchuk S.V. (eds.) Moscow, Leningrad, Academy of Sciences of the Soviet Union, p. 494-498 (in Russian)]

Борисова И.В. (1972) Сезонная динамика растительного сообщества. Полевая геоботаника. Том 4. Лавренко Е.М., Корчагин А.А. (ред.) Ленинград, Наука, с. 5-94 [Borisova I.V. (1972) Seasonal dynamics of a plant community. Field geobotany. Vol. 4. Lavrenko E.M., Korchagin A.A. (eds.) Leningrad, Nauka, p. 5-94 (in Russian)]

Борисова-Гуленкова М.А. (1960) Ритм сезонного развития растений луговой степи. Бюллетень Московского общества испытателей природы. Отдел биологический, 65(6): 78-91 [Borisova-Gulenkova M.A. (1960) Seasonal rhythms of plant development in the meadow steppe. Bulletin of Moscow Society of Naturalists. Biological series [Byulleten' Moskovskogo obshchestva ispytatelej prirody. Otdel biologicheskij], 65(6): 78-91 (in Russian)]

Денисова Г.М. (1960) Ритм сезонного развития луговых растений низовий Северной Двины. Вопросы биологии растений. Bыn. 57 (4). Серебряков И.Г. (ред.) М., Московский городской педагогический институт им. В.П. Потемкина, с. 87-106 [Denisova G.M. (1960) Seasonal rhythms of meadow plant development in the lower reaches of the Northern Dvina. Questions plants biology. Vol. 57. Issue 4. Serebrjakov I.G. (ed.) Moscow, V.P. Potemkin Moscow City Pedagogical Institute, p. 87-106 (in Russian)]

Жмылев П.Ю., Жмылева А.П., Карпухина Е.А., Титовец А.В. (2001) Возможные причины изменения сезонного развития растений в связи с потеплением климата. Вестник РУДН. Серия Экология и безопасность жизнедеятельности, 9: 98-103 [Zhmylev P.Yu., Zhmyleva A.P., Karpukhina E.A., Titovetc A.V. (2001) Possible reasons of changes in seasonal plant development in connection with climate warmening. RUDN Journal of Ecology and Life Safety [Vestnik RUDN. Seriya Ekologiya i bezopasnost zhiznedeyatelnosti], 9: 98-103 (in Russian)]

Жмылева А.П., Карпухина Е.А., Жмылев П.Ю. (2011) Фенологическая реакция лесных растений на потепление климата: рано- и поздноцветущие виды. Вестник РУДН. Серия Экология и безопасность жизнедеятельности, 2: 5-15 [Zhmyleva A.P., Karpukhina E.A., Zhmylev P.Ju. (2011) Influence of cllimate warmening on flowering time of early and lately flowering forest plants. RUDN Journal of Ecology and Life Safety [Vestnik RUDN. Seriya Ekologiya i bezopasnost zhiznedeyatelnosti], 2: 5-15 (in Russian)]

Королюк А.Ю., Макунина Н.И. (2001) Луговые степи и остепненные луга Алтае-Саянской горной области. Порядок Stipetalia sibiricae, союз Aconito barbati-Poion transbaicalicae. Krylovia. Сибирский ботанический журнал, 3(2): 35-49 [Korolyuk A.Yu., Makunina N.I. (2001) The AltaySayany mountain system meadow steppes and steppe meadows. Order Stipetalia sibiricae, alliance Aconito barbati-Poion transbaicalicae. Krylovia. Siberian Botanical Journal [Krylovia. Sibirskij botanicheskij zhurnal], 3(2): 35-49 (in Russian)]

Никифоров А.Р. (2010) Сезонное развитие и ритм побегообразования растений Lagoseris callicephala (Asteraceae) - эндемика горного Крыма. Бюллетень Никитского ботанического сада, 101: 16-18 [Nikiforov A.R. (2010) The seasonal development and rhythm 
of shoots formation Lagoseris callicephala (Asteraceae), endemic plant of Mountain Crimea. Bulletin of State Nikita Botanical Garden [Byulleten' Nikitskogo botanicheskogo sada], 101: 16-18 (in Russian)]

Никифоров А.P. (2011) Сезонное развитие и онтогенез эндемика горного Крыма Silene jailensis (Caryophyllaceae). Ботанический журнал, 96(2): 230-236 [Nikiforov A.R. (2011) The seasonal development and ontogenesis of Silene jailensis (Caryophyllaceae), an endemic of the mountain Crimea. Botanical Journal [Botanicheskiy Zhurnal], 96(2): 230-236 (in Russian)]

Олишевская Г.А. (2011) Сезонный ритм развития некоторых представителей рода Ветреница Aneтопе (Ranunculaceae) в Приморском крае. Вестник Северо-Восточного научного иентра ДВО РАН, 3: 77-82 [Olishevskaya G.A. (2011) Seasonal development rhythm of some species of the Anemone genus in Primorsky territory. Bulletin of the North-East Science Center [Vestnik SeveroVostochnogo nauchnogo tsentra DVO RAN], 3: 77-82 (in Russian)]

Сабинин Д.А. (1957) О ритмичности строения и роста растений. Ботанический журнал, 42(7): 991-1010 [Sabinin D.A. (1957) On the rhythmical nature of plant structure and growth. Botanical journal [Botanicheskiy Zhurnal], 42(7): 991-1010 (in Russian)]

Серебряков И.Г. (1947) О ритме сезонного развития растений подмосковных лесов. Becmник Московского государственного университета. Серия: Биология, 6: 75-108 [Serebryakov I.G. (1947) On the seasonal rhythms of plant development in the forests of Moscow Region. Bulletin of Moscow State University. Series: Biology [Vestnik Moskovskogo gosudarstvennogo universiteta. Seriya: Biologiya], 6: 75-108 (in Russian)]

Серебряков И.Г. (1966) Соотношение внутренних и внешних факторов в годичном ритме развития растений (к истории вопроса). Ботанический журнал, 51(7): 923-938 [Serebryakov I.G. (1966) A balance of external and internal factors in annual rhythms of plant development (historical background). Botanical Journal [Botanicheskiy zhurnal], 51(7): 923-938 (in Russian)]

Серебрякова Т.И. (1956) Побегообразование и ритм сезонного развития растений заливных лугов Средней Оки. Ученые записки. Bыn. 97, №3. Уранов А.А. (ред.) М., МГПИ им. В.И. Ленина, с. 45-120 [Serebryakova T.I. (1956) Shoot formation and seasonal rhythms of plant development in the Middle Oka plain meadows. Scientific notes. Vol. 97, №3. Uranov A.A. (ed.) Moscow, V.I. Lenin Moscow State Pedagogical Institute, p. 45-120 (in Russian)]

Серебрякова Т.И. (1971) Морфогенез побегов и эволюиия жизненных форм злаков. М., Наука, 359 с. [Serebryakova T.I. (1971) Morphology of shoots and evolution of life forms of grasses. Moscow, Nauka, 359 p. (in Russian)]

Серебрякова Т.И. (1976) Некоторые итоги ритмологических исследований в разных ботанико-географических зонах СССР. Проблемы экологической морфологии растений. Серебрякова Т.И. (ред.) М., Наука, с. 216-238 [Serebryakova T.I. (1976) On some outcomes of rhythmological research in diverse botanical and geographical zones of the USSR. Problems of the ecological morphology of plants. Serebryakova T.I. (ed.) Moscow, Nauka, p. 216-238 (in Russian)]

Смелов С.П. (1966) Теоретические основы луговодства. М., Колос, 367 с. [Smelov S.P. (1966) Theoretical bases of grassland science. Moscow, Kolos, 367 p. (in Russian)]

Черемушкина В.А. (2004) Биология луков Евразии. Новосибирск, Наука, 280 с. [Cheryomushkina V.A. (2004) Biology of Allium species in Eurasia. Novosibirsk, Nauka, 280 p. (in Russian)] 
Шилова Н.В. (1988) Ритмы роста и пути структурной адаптащии тундровых растений. Л., Наука, 215 c. [Shilova N.V. (1988) Rhythms of growth and trends in structural adaptation of tundra plants. Leningrad, Nauka, 215 p. (in Russian)]

Ahas R., Jaagus J., Aasa A. (2000) The phenological calendar of Estonia and its correlation with mean air temperature. International Journal of Biometeorology, 44(4): 159-166

Beaubien E., Hamann A. (2011) Spring flowering response to climate change between 1936 and 2006 in Alberta, Canada. BioScience, 61(7): 514-524

Ermakov N., Maltseva T. (1999) Phytosociological peculiarities of South Siberian forest meadows. Annali di Botanica, 57: 63-72

Gorchakova A.Y. (2013) On rhythm-types in the development of boreal cereals. World Applied Sciences Journal, 26(11): 1520-1525

Shorina N.I., Derzhavina N.M. (2015) On mode of rythmological evolution of ferns. Turczaninowia, 18(1): 67-81 (in Russian)

Smith A.R. (1972) Prunella L. Flora Europaea. Vol. 3. Diapensiaceae to Myoporaceae. Cambridge University Press, p. 162

Xi-wen L., Hedge I.C. (1994) Prunella Linnaeus, Sp. Pl. 2:600. 1753. Flora of China. Vol. 17. Verbenaceae through Solanaceae. Beijing, Science Press, St. Louis, Missouri Botanical Garden, p. $134-135$

Wielgolaski F.E. (2001) Phenological modifications in plants by various edaphic factors. International Journal of Biometeorology, 45(4): 196-202 